\title{
Military and Religion
}

\author{
Yagil Levy
}

\section{Contents}

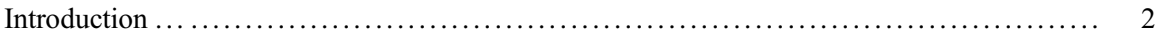

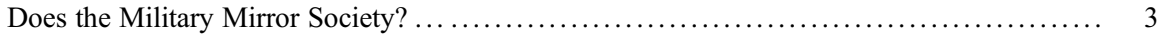

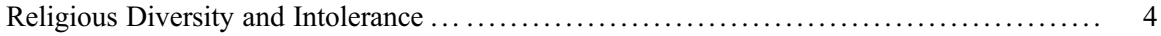

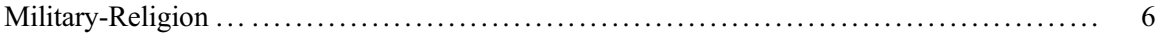

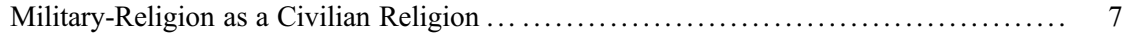

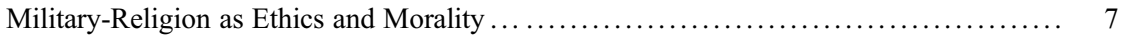

Military-Religion as a Liaison Service ...................................... 8

Military-Religion as a Psychological Resource ................................. 8

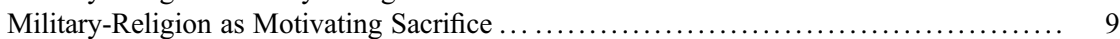

Military-Religion as a Social Status and Symbolic Capital ........................ 11

Military-Religion as Good Soldiering ....................................... 11

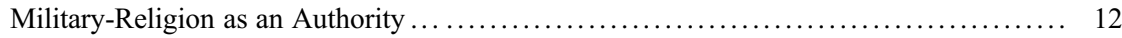

How Does Military-Religion Affect Society? ................................. 13

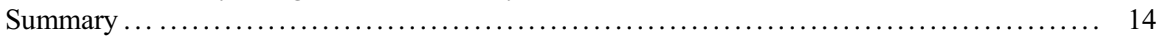

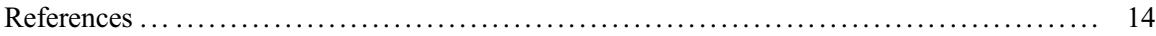

\section{Abstract}

In the post-Cold War era, there were many indications that religious authorities had expanded their influence within militaries, leading to growing interference in military affairs and provoking political debates. This chapter focuses on the relations between the military and religion. It starts by addressing the extent to which military-religion relations reflect the status of religion and the debates about its place in the broader society. Thereafter, it deals with religious diversity and its possible impact on religious intolerance, leading to the main section in

Y. Levy $(\square)$

Department of Sociology, Political Science and Communication, The Open University of Israel, Ra'anana, Israel

e-mail: yagille@openu.ac.il

(C) The Author(s) 2020

A. Sookermany (ed.), Handbook of Military Sciences, https://doi.org/10.1007/978-3-030-02866-4_32-1 
which the key forms of "military-religion" are mapped, that is, the way religiosity is reinterpreted and militarily harnessed. Finally, the impact of military-religion on society are assessed.

\section{Keywords}

Desecularization $\cdot$ Military ethics $\cdot$ Military-religion $\cdot$ Religionization $\cdot$ Religious diversity $\cdot$ Theocratization

\section{Introduction}

In the post-Cold War era, there were many indications that religious authorities had expanded their influence within the military, leading to growing interference in military affairs and provoking political debates. However, as Ron Hassner (2016a) identified, the scholarship on religion in the military lags behind post-Cold War developments, especially those prevalent in the US military engagements in Iraq and Afghanistan. Nonetheless, he considers the most developed area to be the study of religion in the context of civil-military relations.

Without an explicit agenda for filling in these gaps, this chapter focuses on the relations between the military and religion by mapping the main literature. It begins by addressing the extent to which military-religion relations reflect the status of religion and the debates about its place in the broader society. Thereafter, it deals with religious diversity and its optional impact on religious intolerance, leading to the main section where the key forms of "military-religion" are mapped, that is, the way religiosity is reinterpreted and militarily harnessed. Finally, the impact of military-religion on society are assessed.

The topic of relations between the military and religion is significant within the sphere of military-society relations because it captures several of the latter's domains: the extent to which the military reflects broader society, religiously motivated changes in the social make-up of the ranks, and the social hierarchies created within them, diversity management, legitimation of violence and sacrifice, and more.

The military is conceptualized here in two dimensions: as an institution but also as a social sphere in which various groups interact and bargain over its character and identity. Religion is also conceptualized in two dimensions: as a set of symbols, identities, and values, and in terms of the religious actors who promote them, such as religious groups, churches, and chaplains.

Historically, the modern military is associated with secularism. Military organizations, at least of the Western type, are characterized as secular bureaucracies divorced from religious foundations. They are guided by formal rules rather than religious principles, and the recruitment and promotion of their personnel is conducted on the basis of merit rather than religious affiliation. Rational-legal principles, as ideally characterized by Weber, governed the military as a modern bureaucracy in sharp contrast to the traditional authority that predominated in premodern militaries (Soeters 2018, pp. 9-15). Nevertheless, not only have 
militaries not been completely divorced from religiosity, but their permeation by religious authorities and trends has increased during and since the Cold-War era, as Hassner (2016a) noted.

The point of departure of this chapter is that since the 1980s, modern religion has returned to the public sphere in Western societies. This "deprivatization" of religion, as famously conceptualized by José Casanova (1994), is "the process whereby religion abandons its assigned place in the private sphere and enters the undifferentiated public sphere of civil society to take part in the ongoing process of contestation, discursive legitimation, and redrawing of the boundaries" (pp. 65-66). The public reemergence of Protestant fundamentalism as a force in American politics is one example (p. 3). As part of this process, religious institutions and movements try to reinforce their relationships with the military. However, this chapter will not engage with the debated issue about the extent to which militaries became more or less desecularized (or religionized) (see Levy 2020); desecularization comprises a strengthening of religious elements in the military's culture, symbols, ethics, and conduct (p. 3).

\section{Does the Military Mirror Society?}

According to conventional wisdom, militaries largely mirror the processes taking place in the surrounding society, and do so without exception in affairs of religion, that is, the extent to which military-religion relations reflect the status of religion and the debates about its place in the broader society (Hassner 2014; Patterson 2014). Nevertheless, this argument does not consider variations in the level of the diffusion of religious values into the military. Here are some variations as suggested by the existing literature on military-religion relations.

First, socialization of soldiers towards readiness to sacrifice is inevitably imbued with nationalist sentiments at a level higher than that in the broader society. To this end, religious symbols are used as tools to recruit, mobilize, and motivate soldiers (see Hassner 2014).

Second, the level of secularization in society may yield contradictory outcomes for the military. The trends of denationalization, secularization, liberalization, and demilitarization of politics that take place in society may be reflected to a lesser extent in the military, where even opposite trends may also occur. In this case, extramilitary processes may even encourage religious groups and movements to improve their position within the military, based on the assumption that, as a conservative organization, the military can be more attentive than civilian sectors to religious and nationalist values.

In this context, we can understand the evangelization of the US military precisely in the post-Vietnam era. Although society became more religiously diversified and more secular during the 1960s (Loveland 2014, pp. 17-19), the evangelists increased their influence within the military. As Andrew Bacevich (2005, pp. 139-144) maintained, the evangelists filled the vacuum created by the dwindling number of military chaplains provided by mainline Protestant denominations during the 
unpopular Vietnam War, so they were in a good starting position thereafter. The military, for its part, allied with the evangelical movement - an alliance that was enhanced during the Reagan administration. This movement had a clear purpose: to reduce the emerging division between soldiers and society encouraged by the liberal elites' overt lack of respect for the military. Therefore, military commanders encouraged the growing involvement of evangelical chaplains to inspire and educate the troops.

Japan offers another example, especially since the 1980s, when the Japanese SelfDefense Forces (SDF) privileged the Shinto by cultivating private relations with their shrines, while treating other religious belief systems in a more neutral manner. It used Shinto to encourage national loyalty and military morale in an alliance that suited the SDF's needs more than alliances with other religions (Skabelund and Ishikawa 2014).

At the same time, desecularization in society empowers groups associated with religious and nationalist values, thus encouraging and legitimizing their attempts to culturally affect the ranks by amplifying nationalist and religious socialization. This was the situation in the Israeli military following the failure to resolve the IsraeliPalestinian conflict and the outbreak of the Second Intifada in 2000. Viewing the hostilities as a struggle between Jews and non-Jews, religious and right-wing groups promoted desecularization of politics (Ram 2008, pp. 69-71), which provided a tailwind to intra-military endeavors to religiously socialize the troops (Levy 2016, p. 322). This rule works in the opposite direction as well. Liberalization in society may help secular groups curb intra-military socialization informed by religious or other conservative trends, as has been the case since the 1990s when many militaries lifted the bans prohibiting gays and lesbians from serving equally.

Third, as these cases show, and as Ines Michalowski (2015) argued, the military may demonstrate a high degree of autonomy vis-à-vis its social environment and resemble it less closely when its organizational needs, mainly with regard to human resources, constrain its policies. For example, as Michalowski asserted, the need to attract new recruits, maintain social cohesion, and promote equality and religious liberty led the French Armed Forces to accommodate the needs of religious soldiers to a greater extent than in France's public sphere.

Surely, these interrelations work differently in conscript and volunteer forces. Conscript militaries reflect religion in society to a greater extent since they are more permeable to religious influences, and more committed to tolerating the religious needs of their recruits (Rosman-Stollman 2008, p. 617).

\section{Religious Diversity and Intolerance}

In part response to the empowerment of identity politics in society, of which the deprivatization of religion is an integral part, and given that the deprivatization of religion encourages militaries to largely mirror cultural trends in the wider society, militaries promote religious diversity as a layer of diversity management. They accommodate religious requests and recognize individuals' right to practice their religion by providing chaplains (or religious teachers), respecting dietary rules, 
permitting religious apparel, and allowing time off for religious observance (Michalowski 2015). At best, diversity in the military helps mitigate extra-military tensions, as seen in the impact of the work of Muslim imams in the British military chaplaincy (Hafiz 2015).

Policies of diversity operate within a legal context of state-religion relations. Thus, for example, in the USA, tension around the work of evangelical chaplains arose between the two guarantees of the First Amendment: the right to practice one's own religion freely and the restriction on the federal government's endorsement of any particular religious belief or practice (Cook 2014, p. 181). In Japan, similar constitutional obligations required the SDF to respect the religious freedom of its personnel and not to engage with, or support, any religious practices; thus, the military has never had a chaplain service (Skabelund and Ishikawa 2014).

However, the character and boundaries of diversity are largely determined by the bargaining power of the groups involved, while their demands are largely bounded by the nature of their general agenda. Unlike other groups such as ethnic minorities, religious groups may seek to reshape military culture (Lomsky-Feder and Ben-Ari 2013). Furthermore, extra-military religious actors, such as churches and other religious associations, may gain a foothold within the military and thus an advantage over other groups.

Against this background, the military command may attempt to isolate the troops from religious influence that triggers intra-military tensions. For example, in the multifaith Indian Army, the command organizes its units around ethnic, rather than religious identities (Ahuja 2014, pp. 164-165). Furthermore, the military posts religious teachers instead of chaplains. These teachers must hold junior officer rank even if they are allowed to wear civilian clothes, but they are trained to socialize soldiers towards religious harmony and adherence to military rules (Ahuja 2014, 4359-4365; Rosman-Stollman 2015, p. 453).

Conversely, if the command fails to isolate the military from religious influences, the promotion of diversity may actually yield the opposite result - religious intolerance, or at least religious inequality, such as in the case of Japan's Shinto. As noted earlier, the US military encouraged the engagement of the evangelical movement in the military. However, this move has not promoted diversity. As early as the late 1950s, believing that their particular faith was the only "true Christianity," the evangelical movement regarded their military chaplains as fulfilling a missionary agenda aimed, inter alia, at converting military personnel to their faith. In this spirit, the evangelicals challenged military programs such as the Protestant General Service, which was adapted to the religious needs of a broader audience. Committed to the obligation to promote religious diversity, the military allowed evangelical chaplains to conduct separate services, departing from the previous, unified curriculum (Loveland 2014, pp. 170-188). Since the 1990s, for the first time, proselytizing became an issue in the military when the evangelical chaplains claimed the right to evangelize under the guise of the free exercise of religion, while simultaneously defending their right to incorporate sectarian content in public prayers (Loveland 2014, pp. 170-188). By 2012, evangelicals had taken over $60 \%$ of the military chaplaincy posts, while only about $17 \%$ of service members identified as evangelical 
(Military Association of Atheists and Freethinkers 2012). However, the military establishment, albeit hesitantly and insufficiently, did contain the religious discrimination and proselytizing (Banerjee 2008; Hansen 2012, p. 197; Michaelson 2010).

A similar picture emerged in the Israel Defense Forces (IDF). Since the late 1980s, the conscript military has experienced a growing presence of (Orthodox) religious conscripts in combat units. This culturally marginalized group became motivated to use the military as a vehicle for social mobility and influence. Facing a lack of personnel caused by the decline in the motivation of the secular middle class to serve in combat roles, the IDF command encouraged programs integrating religious males into the ranks without compromising their religious faith. It also promoted religious diversity by strictly enforcing rules regarding dietary laws and observance of the Sabbath for all soldiers, in line with the compromise that had already been laid out in the state's first years by both secular and religious parties to enable religious youth to serve in the military without compromising their religious beliefs. In addition, since the 2000s, the Military Rabbinate has expanded its role from providing religious services to the socialization of secular soldiers (Cohen et al. 2016). It follows that, as in the case of the US military, the IDF allied with religious groups; the latter attempted to increase their stronghold just when the military was experiencing a process of liberalization and secularization largely reflected in the decline in motivation of the secular middle class (see Lebel 2016).

However, the more the religious presence increased, the more the religious sector translated it into demands that sought to reshape the military's culture and policies to make them more religious - demands to which the command acquiesced. This was most significantly manifest in the limits imposed on the equal service of women in the military to allay religious male conscripts' concerns about the violation of the rules of modesty. The command accepted the demands of the rabbis (the heads of the institutions where the religious soldiers had been educated) that religious men and secular women be kept separate in field units (Levy 2016).

As both cases show, it was the command's increasing reliance on the resources provided by religious actors that led to the shaping of new forms of military-religion.

\section{Military-Religion}

While the literature has addressed the topic of "religion in the military" (the largest contribution being Hassner's volume of 2014, cited extensively in this chapter), the concept of "military-religion" has not been developed. Religion in the military may have two interrelated meanings: the diffusion of religion into the military, and the increasing role played by military chaplains. While the first implies a preexisting culture that manifests itself in the ranks in a specific way, the second has been defined correctly by Hassner as a "narrow subject" (2014, p. 4).

By contrast, "military-religion" is not a unified culture. It means that an extra-military, preexisting religion, is diffused into the military but then may be reinterpreted and militarily harnessed in several domains and thus morph into multiple forms. These forms deviate from the confessional character of chaplains 
and their associated churches and are not exclusively promoted, legitimated, or mediated by military chaplains. This section maps some of the main forms of military-religion that can be drawn from the existing literature on military-religion relations.

\section{Military-Religion as a Civilian Religion}

In administering religious diversity, military-religion basically has similar content to religion in the civil sphere in terms of respecting religious practices. However, the content can be restrained to isolate the military from religious conflicts (as in the case of the Indian army) or, conversely, can be radicalized (as in the case of evangelization).

\section{Military-Religion as Ethics and Morality}

New ethical dilemmas emerged following the changing nature of warfare that saw growing military engagement with noncombatants in urban conflicts, especially among Muslim communities. Military chaplains stepped into the vacuum created by the deficient provision of spiritual care and answered the spiritual and religious questions of both soldiers and commanders prompted by these new ethical dilemmas (Todd and Butler 2013). After all, the ethics of the just war were traditionally rooted in theological writing until they were supplanted by modern laws. In the post-Cold War era, chaplains became engaged in, and were trained to respond to, these issues, unlike the weakness they had demonstrated in this regard during the Vietnam War (Rock 2011).

Similarly, in the British army, with the empowerment of legal advisors, much of the work of defining what is moral is dealt with by asking what is legally permissible. In the vacuum this creates, chaplains (whose presence has increased) with close contacts with military commanders are often called on to advise on moral issues and play a key role in setting the moral limits of responses to insurgencies involving the treatment of noncombatants (Sedgwick 2013).

Religious ethics may have helped restrain aggressiveness among British troops as part of Christian culture's historical influence on the moral conduct of the soldiers (Snape 2007, p. 204). In contemporary wars, many chaplains see restraint as a component of the British military tradition of honor that should be integrated within operational behavior as part of military ethics. Some have even criticized military policies in accordance with the values of their faith communities (Todd 2009). Similarly, in the Canadian Forces, uncertainty about values emerged following cases of impropriety and abuse that occurred during the peacekeeping operation in Somalia in 1991. In the wake of this uncertainty, moral and ethical training featured more prominently, with chaplains playing an active role (Rennick 2014, pp. 52-53).

A different picture emerged in the US military. The portrayal of the war in Iraq and Afghanistan as a religious war, a clash between American values and Islamism (Marsden 2011, pp. 338-339), with "Jesus Killed Mohammed" as one of 
its symbols, enabled the legitimation of aggression (Sharlet 2009). Religious socialization even encouraged anti-Muslim socialization in the military, in part by chaplains (Cook 2014, pp. 191-192). Similarly, in 2008, chaplains famously encouraged soldiers to spread messages of Christian faith among Afghanistan's Muslim population (Pike 2009, pp. 9-10). Furthermore, if moderate chaplains fail to encourage soldiers to prevent brutality, they often assume a confessional role by listening and consoling those soldiers afflicted by guilt, and reassuring them that their actions were justifiable and their guilt unwarranted (Carlson 2009, pp. 58-61).

True, in the official guidelines of the US military it is clearly expected that chaplains act as moral checks, including criticizing commanders' policies and decisions, and reporting immoral practices during combat. Nonetheless, there is no evidence that chaplains have ever acted in that capacity (Hassner 2016b, 2017-2020). Formally, events of misconduct (such as the torture of Iraqi prisoners at Abu Ghraib that came to light in 2004) encouraged commanders to utilize the chaplaincy for promoting training programs aimed at improving ethical conduct (Van Dyken 2008).

\section{Military-Religion as a Liaison Service}

In Iraq and Afghanistan, US chaplains provided liaison services. They were tasked with communicating with local religious leaders to establish good working relations and function as trust-builders. As part of this policy, chaplains even worked to resolve tensions following confusing incidents that might have ignited hostilities (Carlson 2009, pp. 54-57). In 2009, this expanded role was institutionalized in the military doctrine (Patterson 2011, pp. 99-100). Furthermore, chaplains' roles in advising commanders about religious issues expanded as well, even in the British military where chaplains were not tasked with a formal liaison or advisory role (Gutkowski and Wilkes 2011, pp. 114-118).

\section{Military-Religion as a Psychological Resource}

Historically, chaplains assumed a primary position in roles as motivators alongside their conventional religious obligations (Hassner 2016a, p. 320); this role has expanded during the new wars. In the US military, chaplains create group rituals along with advisory meetings that offer soldiers psychological support by developing a sense of cohesion, camaraderie, and an emotional outlet through which the soldiers can cope with their fears, traumas, and even PTSD (Hassner 2016a, pp. 324-325). This kind of service does not necessarily involve religious issues, especially when offered to soldiers of different faiths. Ceremonially, the chaplains often lay their hands on the shoulders of the soldier in a gesture that highlights the power of touch as an element of healing (Walden 2011, pp. 33-37).

Indeed, "spirituality," as an ambiguous concept, has become a valuable merit associated with physical resilience and ethical attitudes (which American commanders reinforced when the counterinsurgency strategy was launched in Iraq and 
Afghanistan). Two of the three dimensions of spirituality in individuals are prayer/ personal piety and connection to a faith community (Wester 2014). So, blurred lines exist between spirituality and religion, and spirituality may even appear as a softer, and hence less debated, form of religion.

To better understand the chaplains' power, the expression of fear by soldiers is perceived as a deviation from the masculine norm of military courage, and seeking psychological support services may mark the individual as "weak." Nonetheless, chaplains legitimize the soldiers' right to be fearful by listening to them empathically in what can be seen as confessional sessions, and addressing these fears by using a religiously oriented tool kit that includes organizing public prayers and physical touch.

Another example of this quasi-psychologist role undertaken by chaplains is the expanding role of the Military Rabbinate in Israel. In Operation Cast Lead against Hamas-ruled Gaza in December 2008-January 2009, military and civilian rabbis joined the ranks to "spiritually elevate" the soldiers. Among other things, the rabbis helped the soldiers deal with their fears concerning the fighting in the densely populated neighborhoods of Gaza (Levy 2020, p. 16). Providing mental support can be seen as an extension of Jewish theological writing on the rules of war about the duty to maintain morale within the ranks (Cohen 2013, pp. 155-156).

\section{Military-Religion as Motivating Sacrifice}

A growing reluctance in society to sacrifice one's life in war, evident in the syndrome of casualty sensitivity which has been on the rise since the Vietnam War, encouraged militaries to seek ways to justify such sacrifices, especially the ultimate sacrifice, death (Ben-Ari 2005). Furthermore, since the 1990s, postmodern values have increasingly infiltrated the military in many industrialized democracies and challenged the traditional model of military culture that values comrades, service to the nation, obedience, conformity to the group, and sacrifice (Patterson 2014, pp. 235-236).

Hence religion can be used to motivate military sacrifices by portraying wars as religious wars and to socialize the troops accordingly. In the US military, President George W. Bush described the reaction needed after the September 11 attacks as a "crusade," and this perception became reflected in the rhetoric of many commanders (Marsden 2011, pp. 338-339). Officers described America's enemy as a spiritual enemy, the battle against which required religious values (Millonig 2006, pp. 6-7). More extreme views even theologized the mission, for example, as in one colonel's statement that, "The coalition [in the Iraq War] was merely a tool used by God to liberate Iraq from Saddam's tyranny" (Anonymous 2011, p. 94). In this spirit, evangelical chaplains portrayed the war in Iraq and Afghanistan as a religious war demanding unquestioned sacrifices (Cook 2014, pp. 191-192; Sharlet 2009).

In Israel, the religionization of politics has expanded since the 2000s in escalated clashes between Israel and the Palestinians. Subsequently, a theological discourse has permeated the military and played a significant role in Israel's wars against Gaza 
since 2008, promoted by the increasing presence of religious combatants and the empowerment of the Military Rabbinate. In Operation Cast Lead, rabbis portrayed the battles as a campaign against the modern incarnation of Amalek, the first tribe that attacked Israel after the exodus from Egypt. For this sin, God commanded that Amalek and his name be absolutely wiped out, without sparing women and children. Escalation of this rhetoric was revealed later in the 2014 Operation Protective Edge when a religious brigade commander unprecedentedly issued a "battle order" in which he called on his soldiers to fight "to wipe out an enemy" who "curses, blasphemes and scorns the God of Israel." He thus presented the battle against Gaza as a religious war (Levy 2016, pp. 315-317).

In general, religious portrayal helps enhance the social willingness to sacrifice, most notably by using religion to define what constitutes a threat (Hassner 2014, p. 5) and by training soldiers to believe in the absolute logic of right and wrong (Eroukhmanoff 2016, p. 372). Religion may take the sacrifice out of the cost-benefit equation since "the sufferings of the soldier are endured because the benefits of the social entity he dies for exceed the cost of his life" (Brænder 2009, p. 27).

Particularly instrumental is the religious idea of the divine chosenness of a nation (Smith 2003). Religion then helps portray the enemy's nation as inferior by extolling the superior virtues of one's own. Indeed, the Taliban were dehumanized for worshipping a different, "false" god rather than the West's "true" God (Toros and Mavelli 2014). Mobilization for war can be based on symbolic exclusions marking and legitimating ethnic boundaries and hierarchies (see Gorski and TürkmenDervişoğlu 2013, pp. 202-203). A sense of exclusiveness and superiority thus makes the war socially meaningful and justifies sacrifices. Sacrifice is not demanded for the protection of land or economic resources but for the very identity of the fighting nation and its God-given moral beliefs.

For good reason, regions with higher proportions of evangelical Protestants consistently show higher enlistment rates than those with predominantly mainstream Protestants and Catholics (Maley and Hawkins 2018). Similar excessive motivation has been evident in the Israeli religious generation since the 1980s (Levy 2016). Likewise, religious narratives played an important role in motivating sacrifice among young Iranians during the bloody Iran-Iraq War (1980-1988) (Rouhi 2014).

At the same time, this definition of the threat and the inferior status of the enemy also help justify the use of force in the new debated wars, as the case of Israel exemplifies. In Cast Lead, by portraying the Gazans as Amalek, rabbis encouraged the soldiers not to show mercy to the Gazan enemy and thus to use an aggressive fire policy against enemy civilians, especially to spare the lives of Israeli soldiers. Such legitimacy is necessary in order to use aggressiveness to shift risk from one's own soldiers onto enemy civilians and hence cope with the casualty sensitivity syndrome (see Shaw 2002). When questions about the use of force arise, religion may redefine the war as a more crucial endeavor and also help demonize the enemy, making them easier to kill (Johnson and Reeve 2013, p. 75). 


\section{Military-Religion as a Social Status and Symbolic Capital}

If public and military discourse as well as military chaplains inculcate in the soldiers the notion that military sacrifice is praiseworthy in religious terms, the status of those whose sacrifice is associated with the military's perceived religious mission is also appreciated vis-à-vis other soldiers. Practices of classification, demarcation, and hierarchies are thus created within the military. They can affect the real status of specific groups or at least enhance their self-image and, thus, substantiate their claim to higher status or recognition vis-à-vis other groups.

As Sharlet (2009, p. 42) explained, in the US military, the turn toward evangelical Christianity helped replace race with religion as a more legitimate social categorization in creating a separate identity of religious, white, male soldiers. Belonging to this group engendered a sense of superiority over the rest of society, which was viewed as weak and corrupt, and over soldiers from other origins. Evangelists thus fought a war on two fronts with mutually reinforcing impacts - externally, in Iraq and Afghanistan, and internally, a spiritual war against the rest of society.

Furthermore, the dominant us-versus-them discourse of conflicts waged by the US in Muslim nations shapes the military experiences of Muslim service members. Many of them have reported a questioning of their loyalty, discrimination, public disrespect, and even sanctions (Sandhoff 2011; Curtis 2016, pp. 53-68). In other words, the religious framing of the use of force affects the status of various social groups within the ranks.

In Israel, charged with a strong motivation to sacrifice, religious conscripts and their institutional system of yeshivas pictured a nostalgic return to authentic military values and commitment to decisive victories. Inasmuch as they became more noticeable in the combat units, religious groups portrayed themselves as a new service elite, fulfilling the mission of a Jewish avant-garde vis-à-vis the older, secular, liberal elite which was also perceived as weaker (Lebel 2016).

\section{Military-Religion as Good Soldiering}

The religious impact on intra-military hierarchies may go even further by associating religiosity with good soldiering, enabling religious networks to use their religious faith as "symbolic capital," in Pierre Bourdieu's (1986) terms, thereby claiming recognition of their military authority and competence.

The significance of the association between religious virtues and military competence increased with the overall trend toward postmodernism and liberalism that has spread within the militaries of industrialized democracies. To the extent that secular authorities in the military acknowledge this linkage, they promote religious values within the ranks. For example, in Britain during the two world wars, religion was historically associated with good soldiering (Snape 2007). In 2000, moreover, the British army published a document entitled "Values and Standards," presenting the military's core values. The document uses recognizably Christian virtues such as selfless commitment, courage, discipline, and respect for others, and syncretizes 
them with military virtues (Dobbin and Deakin 2014, p. 84). A comparable impact can be seen in the Canadian Forces, when a Muslim soldier asserted that "Islam really helps me in my duties because the disciplines of the religion carry over into the work ethic in the CF" (cited in Rennick 2014, p. 50).

A more extreme link is evident in the US military. Christianity is viewed by many officers as providing a suitable basis for shaping (or reshaping) the military's culture, and as a means of curtailing the perceived threatening liberalization of this culture. Christianity is associated with courage; it is regarded as an antidote to trends towards gender equality (Millonig 2006, p. 8) and is viewed as a method for combating perceived immorality in the ranks, as well as a means of dealing with stress, loneliness, fear, and guilt. Christianity is also associated with respect for authority and the belief that spirituality is a trait of good military leadership (Anonymous 2011, pp. 113-120, 129-131). It is against this background that military commanders encourage the growing involvement of evangelical chaplains to educate the troops (Bacevich 2005, pp. 139-144).

Similarly, in Israel, in 2002 (during the Second Intifada), the military defined its collective identity as the military of the Jewish democratic state, committed to the strengthening of Jewish identity among its troops and enhancing their links to their land, values, heritage, and people. This trend bolstered the association between soldiering and Jewishness, and hence also privileged the status of religion in the military and increased the influence of rabbis who were seen as having the appropriate tools to re-educate secular soldiers (Levy 2016, p. 322).

\section{Military-Religion as an Authority}

As Chaves (1994) noted, religious authority is legitimated by calling on some supernatural referent such as God. Therefore, intervention by religious authorities in the military may stand in sharp contrast to the basic principles of civilian control of the military in democratic societies, whereby elected civilians autonomously shape and enforce policies regarded as expressing the will of society as a whole, and in a manner guided by legal rules. A clear and unified hierarchy of command, from the political authority to the rank and file, is a prerequisite that might be intolerant of any external intervention. The clash of authorities is a substantial, not only a formal, issue, as we see now.

Intervention by a religious authority can take the form of theocratization whereby religious authorities operate in lieu of, or in tandem with, the civilly sanctioned military system, whose opinions and jurisprudence carry significant symbolic weight (based on Hirschl's [2008] constitutional theocracy). This pattern typifies the case of Israel in which the military has been partly theocratized with the intervention of civilian rabbis in military affairs, as noted above, in the domain of intergender relations (Levy 2016). A clash between the legally prescribed principle of gender equality and the religious principle of women's modesty was apparent.

Another form of theocratization is the creation of dual hierarchies in which the regime controls the military by creating mechanisms of control operated by religious 
authorities that run parallel to the normal military chain of command. Religious authorities can engage in the religious and political socialization of the troops without affecting decision making. This model typified the Parliament army of England in the mid-seventeenth century, as an indirect mechanism of control by Parliament vis-à-vis the King (Herspring 2001, pp. 55-77). In a different manner, the post-revolutionary Iranian military was supervised by the Ideological-Political Directorate whose role was not only to engage in religious socialization but also to influence promotion and other military-related matters in parallel to the formal chain of command (Rosman-Stollman 2008, pp. 620-621).

At the minimum, a clash of authorities can be created even without a clear theocratization, when the location of chaplains within the military hierarchy is blurred because of their affiliation with the churches that send them. In the USA, the churches' endorsement of the chaplains' nomination is required, and it is to their churches that most owe their primary loyalty (Hansen 2012, p. 163). Against this background, clashes over issues like the service of homosexuals (Hansen 2012, pp. 169-170) and proselytizing arose. Furthermore, anti-Muslim socialization undermined the administration's efforts to prevent Muslims from interpreting these campaigns as an anti-Muslim crusade (Cook 2014, pp. 191-192). In a somewhat different format, in Britain, although the churches have lost control over the appointment of the military's Chaplain General (Howson 2011), there is an inherent tension in the chaplains' commitment to their community and to the military, forcing them into a "cultural juggling act" (Todd 2009, p. 78).

\section{How Does Military-Religion Affect Society?}

If the scholarship on the relationships between the military and religion is underdeveloped, the impact of the military on religiosity in society is even more so. Here are three impacts raised in the literature.

First, intra-military practices not only shape the form of military-religion but also create new social categories and even identities that can be extended to civilian society. For example, the US military promoted religious diversity during the world wars. In turn, inspired by pluralistic and universalist visions that permeated American life, groups claimed the extension of their religious rights, gained by military service, to the civil sphere (Stahl 2017).

Second, power relations in the military may be replicated in society. In the context of military-religion relations, for example, the increased integration of religious conscripts in the IDF created a young, religious generation claiming integration within the Israeli power elites, and discarding its previous marginalized status (Lebel 2016).

Third, the military's biases to privilege one religious faith over the other, or secularism over religiosity, affect its relations with other social groups, as attested by the case of the SDF (Hassner 2016a, pp. 318-319). 


\section{Summary}

This chapter aimed at contributing to the underdeveloped literature on the relations between military and religion. This topic became relevant since religious tensions were aggravated by the Western interventions in Iraq and Afghanistan, and the overall trend of deprivatization of religion that inevitably affects militaries as public spheres.

Several insights can be obtained from this chapter. First, scholars should consider variations in the level of the diffusion of religious values into the military in ways that do not symmetrically mirror the processes taking place in the surrounding society. Sometimes, it is secularization in society that can encourage the opposite process in the military. Second, because of the unique character of religious groups, attempts to implement religious diversity may yield the opposite, and unintended consequence of religious intolerance. Third, religiosity is reinterpreted and militarily harnessed, and thus morphs into multiple forms of military-religion. Although this chapter has not engaged with the debate about whether militaries become more or less desecularized, it is safe to conclude that the more military-religion morphs into multiple forms, thereby expanding its domains of influence, the higher the level of desecularization of the military (Levy 2020).

Future research should expand on these areas and further validate or refute the insights presented here. However, studying this topic involves methodological challenges. As Ben-Ari and Levy (2014) suggested, access to the study of the military at large entails both organizational difficulties of entry into the armed forces and issues related to the kinds of knowledge created by researchers. In this case, the issue of unobstructed access to troops is less significant to the extent that religious actors often work along the seamline between the military and society. However, access to combat units to observe religion-in-action may encounter the typical problems. No less significant a challenge is framing the kinds of knowledge expected to be produced. It may take three main forms: (1) empirical-analytic knowledge that typifies most of the studies undertaken and cited in this chapter, such as that pertaining to chaplains; (2) cultural-hermeneutic knowledge that relies on interpretive methods, such as the endeavor to interpret the meanings of social actions, as conducted by Brænder (2009); (3) critical theory aimed at exposing the constraining structures of power, in this case, for example, by showing how militaryreligion is used to legitimize aggressiveness (Levy 2020). The challenges lie ahead.

\section{References}

Ahuja, A. (2014). India. In R. E. Hassner (Ed.), Religion in the military worldwide (pp. 159-178). New York: Cambridge University Press.

Anonymous (US Air Force Officer and Harvard Masters Graduate). (2011). Evangelism in the profession of arms: An evaluation of Evangelical Christian proselytizing in the professional journal of the United States Air Force (Master's thesis, Harvard University, Cambridge, MA).

Bacevich, A. J. (2005). The new American militarism: How Americans are seduced by war. New York: Oxford University Press. 
Banerjee, N. (2008, April 26). Soldier sues army, saying his atheism led to threats. The New York Times.

Ben-Ari, E. (2005). Epilogue: A "good" military death. Armed Forces \& Society, 31(4), 651-664.

Ben-Ari, E., \& Levy, Y. (2014). Getting access to the field: Insider/outsider perspectives. In J. Soeters, P. M. Shields, \& B. Rietjens (Eds.), Routledge handbook of research methods in military studies (pp. 9-18). New York: Routledge.

Bourdieu, P. (1986). The forms of capital. In J. G. Richardson (Ed.), Handbook of theory and research for the sociology of education (pp. 241-258). New York: Greenwood.

Brænder, M. (2009). Justifying the ultimate sacrifice: Civil and military religion in frontline blogs (Doctoral thesis, Aarhus University, Aarhus).

Carlson, J. D. (2009). Cashing in on religion's currency? Ethical challenges for a post-secular military. The Review of Faith \& International Affairs, 7(4), 51-62.

Casanova, J. (1994). Public religions in the modern world. Chicago: University of Chicago Press (Kindle).

Chaves, M. (1994). Secularization as declining religious authority. Social Forces, 72(3), 749-774.

Cohen, S. A. (2013). Divine service? Judaism and Israel's armed forces. Farnham: Ashgate.

Cohen, S., Kampinsky, A., \& Rosman-Stollman, E. (2016). Swimming against the tide: The changing functions and status of chaplains in the Israel Defense Force. Religion, State and Society, 44(1), 65-74.

Cook, M. L. (2014). United States II. In R. E. Hassner (Ed.), Religion in the military worldwide (pp. 181-195). New York: Cambridge University Press.

Curtis, E. E. (2016). Muslim Americans in the military: Centuries of service. Bloomington: Indiana University Press.

Dobbin, V., \& Deakin, S. (2014). United Kingdom. In R. E. Hassner (Ed.), Religion in the military worldwide (pp. 68-89). New York: Cambridge University Press.

Eroukhmanoff, C. (2016). A critical contribution to the "security-religion" nexus: Going beyond the analytical. International Studies Review, 18(2), 366-378.

Gorski, P. S., \& Türkmen-Dervişoğlu, G. (2013). Religion, nationalism, and violence: An integrated approach. Annual Review of Sociology, 39, 193-210.

Gutkowski, S., \& Wilkes, G. (2011). Changing chaplaincy: A contribution to debate over the roles of US and British military chaplains in Afghanistan. Religion, State and Society, 39(1), $111-124$.

Hafiz, A. (2015). Muslim chaplaincy in the UK: The chaplaincy approach as a way to a modern imamate. Religion, State and Society, 43(1), 85-99.

Hansen, K. P. (2012). Military chaplains and religious diversity. New York: Palgrave.

Hassner, R. E. (2014). Introduction. Religion in the military worldwide: Challenges and opportunities. In R. E. Hassner (Ed.), Religion in the military worldwide (pp. 1-19). New York: Cambridge University Press.

Hassner, R. E. (2016a). Hypotheses on religion in the military. International Studies Review, 18(2), 312-332.

Hassner, R. E. (2016b). Religion on the battlefield. Ithaca/London: Cornell University.

Herspring, D. R. (2001). Soldiers, commissars, and chaplains: Civil-military relations since Cromwell. Madison: Rowman \& Littlefield.

Hirschl, R. (2008). The theocratic challenge to constitution drafting in post-conflict states. William and Mary Law Review, 49(4), 1179-1211.

Howson, P. (2011). 'Command and control' in the Royal Army Chaplains' Department: How changes in the method of selecting the chaplain general of the British army have altered the relationship of the churches and the army. Religion, State and Society, 39(1), 63-78.

Johnson, D. D. P., \& Reeve, Z. (2013). The virtues of intolerance: Is religion an adaptation for war. In S. Clarke, R. Powell, \& J. Savulescu (Eds.), Religion, intolerance, and conflict: A scientific and conceptual investigation (pp. 67-87). Oxford: Oxford University Press.

Lebel, U. (2016). The 'immunized integration' of religious-Zionists within Israeli society: The premilitary academy as an institutional model. Social Identities, 22(6), 642-660. 
Levy, Y. (2016). Religious authorities in the military and civilian control: The case of the Israeli Defense Forces. Politics \& Society, 44(2), 305-332.

Levy, Y. (2020). Theorizing desecularization of the military - The US and Israel. Armed Forces \& Society, 46 (1), 92-115.

Lomsky-Feder, E., \& Ben-Ari, E. (2013). Managing diversity in context: Unit level dynamics in the Israel Defense Forces. Armed Forces \& Society, 39(2), 193-212.

Loveland, A. C. (2014). Change and conflict in the U.S. army chaplain corps since 1945. Knoxville: University of Tennessee Press.

Maley, A. J., \& Hawkins, D. N. (2018). The southern military tradition: Sociodemographic factors, cultural legacy, and US army enlistments. Armed Forces \& Society, 44(2), 195-218.

Marsden, L. (2011). Religion, identity and American power in the age of Obama. International Politics, 48(2), 326-343.

Michaelson, D. H. (2010). God exclusion - The constitutional implications of proselytization and religious discrimination in the US military. Brooklyn Law Review, 76(2), 807-836.

Michalowski, I. (2015). What is at stake when Muslims join the ranks? An international comparison of military chaplaincy. Religion, State and Society, 43(1), 41-58.

Military Association of Atheists and Freethinkers. (2012). Military chaplaincy report. Retrieved from https://www.secular.org/files/sca_military_chaplain_report_0.pdf

Millonig, W. (2006). The impact of religious and political affiliation on strategic military decisions and policy recommendations. Carlisle Barracks: US Army War College.

Patterson, E. (2011). Politics in a religious world: Building a religiously literate U.S. foreign policy. New York: Continuum Books.

Patterson, E. (2014). Conclusion. Promising themes, future approaches. In R. E. Hassner (Ed.), Religion in the military worldwide (pp. 227-240). New York: Cambridge University Press.

Pike, S. P. (2009). Go forth and multiply: How the chaplain's actions can have strategic impact in the current operational environment. Newport: Naval War College.

Ram, U. (2008). Why secularism fails? Secular nationalism and religious revivalism in Israel. International Journal of Politics, Culture, and Society, 21(1-4), 57-73.

Rennick, J. B. (2014). Canada. In R. E. Hassner (Ed.), Religion in the military worldwide (pp. 45-67). New York: Cambridge University Press.

Rock, S. (2011). Editorial. Religion, State and Society, 39(1), 1-8.

Rosman-Stollman, E. (2008). Mediating structures and the military: The case of religious soldiers. Armed Forces \& Society, 34(4), 615-638.

Rosman-Stollman, E. (2015). Religious accommodation as a civil-military looking glass: The case of the Indian and Israeli armed forces. Journal of Church and State, 58(3), 440-461.

Rouhi, M. (2014). Iran. In R. E. Hassner (Ed.), Religion in the military worldwide (pp. 143-158). New York: Cambridge University Press.

Sandhoff, M. (2011). Preliminary findings on the experiences of Muslims in the US military: The importance of cross-cultural competence. Paper presented at the Defense Equal Opportunity Management Institute Symposium, Maxwell Air Force Base, Montgomery.

Sedgwick, P. (2013). Terrorism and interrogation, as an issue for chaplains on operations. In A. Todd (Ed.), Military chaplaincy in contention: Chaplains, churches, and the morality of conflict, (explorations in practical, pastoral and empirical theology) (pp. 65-82). Farnham: Ashgate.

Sharlet, J. (2009). Jesus killed Mohammed: The crusade for a Christian military. Harper's Magazine, 318, 31-43.

Shaw, M. (2002). Risk-transfer militarism, small massacres and the historic legitimacy of war. International Relations, 16(3), 343-360.

Skabelund, A., \& Ishikawa, A. (2014). Japan. In R. E. Hassner (Ed.), Religion in the military worldwide (pp. 23-44). New York: Cambridge University Press.

Smith, A. D. (2003). Chosen peoples: Sacred sources of national identity. New York: Oxford University Press.

Snape, M. (2007). God and the British soldier: Religion and the British army in the first and second world wars. Milton Park: Routledge. 
Soeters, J. (2018). Sociology and military studies - Classical and current foundations. London/New York: Taylor and Francis (Kindle).

Stahl, R. Y. (2017). Enlisting faith: How the military chaplaincy shaped religion and state in modern America. Cambridge, MA: Harvard University Press.

Todd, A. (2009). Reflecting ethically with British army chaplains. The Review of Faith \& International Affairs, 7(4), 77-82.

Todd, A., \& Butler, C. (2013). Moral engagements: Morality, mission and military chaplaincy. In A. Todd (Ed.), Military chaplaincy in contention: Chaplains, churches, and the morality of conflict, (explorations in practical, pastoral and empirical theology) (pp. 151-168). Farnham: Ashgate.

Toros, H., \& Mavelli, L. (2014). Collective evil and individual pathology: The depoliticization of violence against Afghan civilians. International Politics, 51(4), 508-524.

Van Dyken, J. (2008). Moving soldiers to the moral high ground. The Army Chaplaincy, (SpringSummer), 17-22.

Walden, K. J. (2011). Challenges faced by Iraq war reservists and their families: A soul care approach for chaplains and pastors. Eugene: Claremont School of Theology.

Wester, E. (2014). Military chaplaincy: Religious leadership and character development. In E. Patterson (Ed.), Military chaplains in Afghanistan, Iraq, and beyond: Advisement and leader engagement in highly religious environments (pp. 147-170). Lanham: Rowman \& Littlefield.

Open Access This chapter is licensed under the terms of the Creative Commons Attribution 4.0 International License (http://creativecommons.org/licenses/by/4.0/), which permits use, sharing, adaptation, distribution and reproduction in any medium or format, as long as you give appropriate credit to the original author(s) and the source, provide a link to the Creative Commons licence and indicate if changes were made.

The images or other third party material in this chapter are included in the chapter's Creative Commons licence, unless indicated otherwise in a credit line to the material. If material is not included in the chapter's Creative Commons licence and your intended use is not permitted by statutory regulation or exceeds the permitted use, you will need to obtain permission directly from the copyright holder.

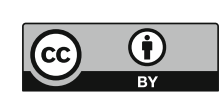

